\title{
INOVASI PELAYANAN PUBLIK MELALUI SOLO DESTINATION DI KOTA SURAKARTA, JAWA TENGAH
}

\author{
Yunita Ratna Sari \\ Universitas Terbuka \\ *Coressponding Author. Email : yunitaratna36@yahoo.com
}

\begin{abstract}
Solo destination is a public service innovation from the Surakarta City Communication dan Information Departement in the form of a mobile based application. The application in Solo Destination consists of various features including culinary, hotels, public facilities, shopping centers, cultural events, community services, children's radio and historic sites. The launching of Solo Destination application service received the MURI award as the first city in Indonesia to provide technology based tourism services through the application. The purpose of this researh is to explain the innovation of public service in the field tourism through Solo Destination. The method used is desk research that utilizes secondary data as a source of literature. The results of the study show taht the implementation of Solo Destination in the Surakarta City provides positive benefits for all parties including the Surakarta City Goverment to provide public services to the public quickly. For the public and tourists can provide services on the potential of Surakarta City easliy and completely
\end{abstract}

Keywords: innovation, public service, Solo Destination.

\begin{abstract}
Abstrak
Solo Destination merupakan inovasi pelayanan publik dari Dinas Komunikasi dan Informatika Kota Surakarta berbentuk aplikasi berbasis mobile. Aplikasi dalam Solo Destination terdiri berbagai fitur antara lain kuliner, pariwisata, hotel, fasilitas umum, pusat perbelanjaan, event budaya, layanan masyarakat, radio anak dan tempat- tempat bersejarah. Peluncuran layanan aplikasi Solo Destination mendapat penghargaan dari Museum Rekor Dunia Indonesia (MURI) sebagai kota pertama di Indonesia yang menyediakan layanan pariwisata berbasis teknologi melalui aplikasi. Penelitian ini dilakukan untuk memaparkan inovasi pelayanan publik bidang pariwisata melalui Solo Destination. Metode yang digunakan adalah desk research, studi ini memanfaatkan data sekunder sebagai sumber literatur. Hasil penelitian menunjukkan bahwa pelaksanaan Solo Destination di Kota Surakarta memberikan manfaat positif bagi semua pihak antara lain bagi pemerintah Kota Surakarta dapat memberikan pelayanan publik kepada masyarakat secara cepat. Bagi masyarakat dan wisatawan dapat memperoleh layanan tentang potensi Kota Surakarta dengan mudah dan lengkap.
\end{abstract}

Kata kunci : inovasi, pelayanan publik, Solo Destination 


\section{PENDAHULUAN}

Pelayanan publik

dapat dinyatakan sebagai segala bentuk pelayanan di sektor publik yang dilaksanakan aparatur pemerintah dalam bentuk penyediaan barang dan atau jasa sesuai kebutuhan masyarakat berdasarkan aturan- aturan hukum perundang- undangan yang berlaku.(Endang,2013:2). Namun faktanya, kualitas pelayanan publik di Indonesia masih buruk. Hal itu dibuktikan dengan dengan data Ombudsman Republik Indonesia Tahun 2018 tentang banyaknya laporan masyarakat terkait pelayanan publik.

\section{Tabel 1}

Jumlah Laporan Masyarakat Berdasarkan Instansi Terlapor Tahun 2018

\begin{tabular}{ccc}
\hline Instansi & Jumlah & \% \\
\hline Pemerintah Daerah & 2.489 & 39,70 \\
Kepolisian & 801 & 12,78 \\
Instansi & 700 & 11,16 \\
Pemerintah/Kementerian & & \\
Badan Pertanahan & 562 & 8,96 \\
Nasional & & \\
BUMN/BUMD & 455 & 7,26 \\
Lain- lain & 263 & 4,19 \\
Lembaga Pendidikan & 203 & 3,24 \\
Negeri & 172 & 2,74 \\
Perbankan & 159 & 2,54 \\
Lembaga Peradilan & 81 & 1,29 \\
Komisi Negara/LNNS & 69 & 1,10 \\
Kejaksaan & 63 & 1,00 \\
Perguruan Tinggi Negeri & 60 & 0,96 \\
Rumah Sakit Pemerintah & 21 & 0,33 \\
TNI & 15 & 0,24 \\
Dewan Perwakilan & & \\
Rakyat (DPR) & 8 & 0,13 \\
Lembaga Pendidikan & & 2,38 \\
Swasta & 149 &
\end{tabular}

Sumber : Ombudsman RI Tahun 2018

Mengacu pada tabel 1, instansi terbanyak yang dilaporkan oleh masyarakat yaitu pemerintah daerah sebanyak 2.489 laporan atau $39,70 \%$ dari total jumlah laporan masyarakat sebanyak 8.314 laporan. Dengan banyaknya jumlah laporan masyarakat tentang pelayanan publik terhadap instansi pemerintah daerah sehingga perlu adanya perubahan tata kelola dalam memberikan pelayanan yang prima kepada masyarakat. Salah satu cara dalam merubah tata kelola pelayanan publik yaitu dengan menciptakan inovasi di bidang pelayanan publik yang efektif dan efisien. Adapun alasan pemerintah daerah harus menciptakan inovasi pelayanan publik karena instansi pemerintah daerah sebagai penyelenggaran pelayanan publik di 
tingkat lokal sekaligus perangkat penyedia pemberi pelayanan. Alasan lainnya yang mendasari pemerintah daerah perlu melakukan inovasi karena pemerintah daerah sangat dekat dengan masyarakat yang dianggap paling mengetahui kebutuhan, keluhan dan masalah yang dihadapi masyarakat di tingkat daerah daripada pemerintah pusat sehingga inovasi yang diciptakan nantinya dapat meningkatkan kemakmuran dan kesejahteraan masyarakat di daerah.(Watson,1997:130131).Disamping itu, dalam UndangUndang Nomor 23 Tahun 2014 tentang Pemerintah Daerah dalam Bab XXI bertajuk inovasi daerah menjelaskan bahwa dalam rangka peningkatan kinerja penyelenggaraan pemerintahan daerah dan dalam upaya peningkatan kualitas layanan, pemerintah daerah dapat melakukan inovasi.

Salah satu inovasi pelayanan publik yang menarik untuk dibahas yaitu Solo Destination di Kota Surakarta, Jawa Tengah. Solo Destinantion merupakan sistem aplikasi terpadu sebagai tool guide yang memudahkan masyarakat baik yang tinggal di Kota Surakarta maupun diluar Kota Surakarta dan wisatawan terdiri atas wisatawan nusantara serta mancanegara agar mudah mengakses layanan dan informasi yang ada di Kota Surakarta. Solo Destination diinisiasi oleh Dinas Perhubungan, Komunikasi dan Informatika Kota Surakarta dan sudah dilaksanakan sejak tahun 2014. Terciptanya Solo Destination dilatarbelakangi bahwa Kota Surakarta atau lebih dikenal dengan sebutan Kota Solo (Sala) merupakan salah satu Kota besar di Provinsi Jawa Tengah dengan luas wilayah $44,04 \mathrm{~km}^{2}$ dengan jumlah penduduk 558.762 jiwa.(dispendukcapil.surakarta.go.id, 2016).
Kota Surakarta berada di tengahtengah Pulau Jawa yang menjadikan Surakarta sebagai daerah perlintasan pertemuan Kota- Kota penting sekaligus Kota penghubung seperti Kota Semarang, Yogyakarta, Surabaya maupun Jakarta. Dengan posisi yang strategis menjadikan Kota Surakarta sebagai pusat perdagangan atau pusat bisnis yang penting bagi daerah di sekitarnya baik yang berbatasan langsung maupun tidak. Perdagangan merupakan urat nadi perekonomian Kota Surakarta yang didaerahnya tidak memiliki potensi sumber daya alam. Sadar tidak mempunyai kekayaan sumber daya alam untuk menopang perekonomian daerah, Kota Surakarta mengembangkan sektor pariwisata. Berbagai kebijakan diarahkan untuk mendorong tumbuhnya pusatpusat perdagangan diiringi dengan munculnya kegiatan produktif masyarakat lainnya terutama industri kreatif.

Sesuai dengan visi Kota Surakarta sebagai Kota Budaya, Mandiri, Maju dan Sejahtera (RPJM 2005- 2025), Kota Surakarta sangat lekat dengan budaya dan kreatifitas. Kedinamisan masyarakat, kebutuhan kecepatan layanan dan informasi serta validitas informasi menjadi entry point bagi Pemerintah Kota Surakarta untuk mendesain sebuah "tool" yang mempermudah masyarakat maupun wisatawan dalam memperoleh informasi dan layanan yang diselenggarakan oleh Pemerintah Kota Surakarta maupun sektor swasta yang menyediakan layanan di Kota Surakarta. Pada awalnya, masyarakat atau wisatawan membutuhkan informasi dan layanan yang ada di Kota Surakarta dengan mendatangi Organisasi Perangkat Daerah (OPD) terkait atau mengunjungi website OPD atau stakeholder penyedia layanan yang diinginkan. Hal itu tentu menjadi 
rumit mengingat jumlah OPD yang jumlahnya puluhan, dapat dibayangkan betapa sulitnya mengingat alamat masing- masing website tersebut. Belum lagi, jumlah stakeholder dari sektor swasta yang jumlahnya puluhan bahkan ratusan. Tentu akan semakin rumit untuk masyarakat maupun wisatawan guna mengakses informasi dan layanan dengan puluhan bahkan ratusan website tersebut. Jika dengan alternatif mendatangi lokasi sumber informasi dan layanan tentu memerlukan waktu dan cost yang tidak sedikit.

Inovasi merupakan salah satu aspek penting dalam perkembangan penyelenggaraan pemerintahan daerah. Inovasi menurut Hamel dalam (Djamaludin, 2012: 34) mendefinisikan inovasi sebagai peralihan dari prinsipprinsip, proses dan praktik- praktik manajemen tradisional atau pergeseran dari bentuk organisasi yang lama dan memberi pengaruh yang signifikan terhadap cara sebuah manajemen yang dijalankan. Sedangkan Said (2007:27), mengartikan inovasi sebagai suatu perubahan yang terencana dengan memperkenalkan teknologi dan penggunaan peralatan baru dalam lingkup instansi. Menurut Rogers (2003:12) menjelaskan inovasi merupakan sebuah ide, praktek atau objek yang dianggap baru oleh individu satu unit adopsi lainnya. Sehingga, inovasi dapat dipahami sebagai pengetahuan baru, cara baru, objek baru, teknologi baru dan penemuan baru. (Suwarno,2010:10). Secara umum, inovasi memiliki beberapa atribut antara lain 1) relative advantage atau keuntungan relatif yaitu sebuah inovasi harus mempunyai keunggulan dan nilai lebih dibandingkan dengan inovasi sebelumnya, 2) compatibility atau kesesuaian yaitu inovasi sebaiknya mempunyai sifat kompatibel atau kesesuaian dengan inovasi yang digantinya, 3) complexity atau kerumitan merupakan dengan sifatnya yang baru, maka inovasi mempunyai tingkat kerumitan yang boleh jadi lebih tinggi dibandingkan dengan inovasi sebelumnya, 4) triability atau kemungkinan dicoba merupakan inovasi hanya bisa diterima apabila telah teruji dan terbukti mempunyai keuntungan atau nilai lebih dibandingkan dengan inovasi yang lama, 5) observasibility atau kemudahan diamati yakni sebuah inovasi harus juga dapat diamati dari segi bagaimana ia bekerja dan menghasilkan sesuatu yang lebih baik. (Rogers, 2003: 219).

Pelaksanaan inovasi dikatakan berhasil apabila inovasi tersebut merupakan kreasi dan implementasi dari proses, produk, layanan dan metode pelayanan baru yang merupakan hasil pengembangan nyata dalam hal efisiensi dan efektivitas atau kualitas pelayanan. (Mulgan dan Alburry, 2003: 3). Pelayanan umum atau pelayanan publik menurut Sedu Wasistiono (2001:51-52). yaitu pemberian jasa baik oleh pemerintah, pihak swasta atas nama pemerintah ataupun pihak swasta kepada masyarakat dengan atau tanpa pembayaran guna memenuhi kebutuhan dan atau kepentingan masyarakat. Selanjutnya menurut Bab 1 Pasal 1 Ayat 1 Undang- Undang Nomor 25 Tahun 2009 yang dimaksud dengan pelayanan publik adalah kegiatan atau rangkaian kegiatan dalam rangka pemenuhan kebutuhan pelayanan sesuai dengan peraturan perundang- undangan bagi setiap warga negara dan penduduk atas barang, jasa dan/atau pelayanan administratif yang disediakan oleh penyelenggara pelayanan publik Berdasarkan pasal 3 Undang- undang Nomor 25 Tahun 2009 menyebutkan 
bahwa tujuan pelayanan pelayanan publik antara lain pertama, terwujudnya batasan dan hubungan yang jelas hak dan tanggungjawab serta kewenangan seluruh pihak yang terkait dengan penyelenggaraan pelayanan publik, kedua, terwujudnya sistem penyelenggaraan pelayanan publik yang layak sesuai dengan asas- asas umum pemerintahan dan koperasi yang baik, ketiga, terpenuhinya penyelenggaraan pelayanan publik sesuai dengan peraturan perundangan dan keempat, terwujudnya perlindungan dan kepastian hukum bagi masyarakat dalam penyelenggaraan pelayanan publik. (Hayat, 2017: 52-53).

Standar pelayanan publik terdiri atas prosedur pelayanan, waktu penyelesaian, biaya pelayanan, produk pelayanan, dasar hukum, kompetensi petugas pelayanan, pengawasan internal dan eksternal, penanganan pengaduan, saran dan masukan serta sarana dan prasarana. (Hardiansyah, 2011: 28-29). Menurut Noor (2013: 112), terdapat beberapa hal yang perlu diperhatikan oleh pemerintah daerah dalam membuat keputusan inovasi antara lain (1) apakah inovasi yang akan dilakukan oleh pemerintah daerah membutuhkan biaya yang besar tetapi dengan tingkat ketidakpastian yang besar, (2) apakah inovasi tersebut akan mengganggu kehidupan sehari- hari masyarakat, (3) apakah inovasi sesuai dengan kebiasaan dan nilai- nilai kehidupan masyarakat dan (5) apakah inovasi sulit digunakan nantinya.

Alasan yang mendasari peneliti mengambil lokus penelitian di Kota Surakarta karena Kota Surakarta sebagai salah satu Kota di Jawa Tengah yang telah mendapat banyak penghargaan di bidang pelayanan publik. Beberapa penghargaan yang diterima oleh Kota Surakarta antara lain Kota Surakarta dinobatkan sebagai salah satu Kota paling inovatif di Indonesia dari Menteri Dalam Negeri.(RRI.co.id,2017). Kemudian Kota Surakarta mendapat penghargaan Dana Racka dari Presiden Joko Widodo sebagai Kota yang dinilai mampu mengelola keuangan daerah dengan baik. Selanjutnya, Kota Surakarta mendapat penghargaan WTP (Wajar Tanpa Pengecualian) delapan tahun berturutturut dari Kementerian Keuangan. (TribunSolo, 2018). Selain itu, Kota Surakarta didaulat sebagai Kota yang memiliki perencanaan dan pencapaian terbaik dalam pembangunan dan memperoleh penghargaan dari Kementerian Perencanaan Pembangunan Nasional (PPN)/Bappenas. (Radar Solo, 2018).

Alasan peneliti membahas Solo Destination karena merupakan inovasi pelayanan publik berbentuk aplikasi terintegrasi city guide, sosial media dan pemantauan lalu lintas berbasis mobile pertama di Indonesia. Sehingga, saat awal lauching Solo Destination mendapatkan penghargaan dari MURI Tahun 2014 sebagai kota pertama di Indonesia yang menyediakan layanan pariwisata berbasis Teknologi dan Informatika. Hal ini menjadi menarik bagi peneliti untuk membahas secara lebih detail mengenai Solo Destination disaat Pemerintah Kota/ Kabupaten lainnya belum banyak melakukan inovasi bidang pariwisata, Kota Surakarta sudah melaunching inovasi pelayanan publik bidang pariwisata secara resmi.

Disamping itu, terdapat berbagai fitur terintegrasi terkait pariwisata dalam aplikasi Solo Destination antara lain tempat- tempat pariwisata, hotel, pusat perbelanjaan, tempat- tempat bersejarah, kuliner dan event budaya. Aplikasi dalam Solo Destination tidak hanya menyediakan fitur- fitur yang berkaitan dengan pariwisata tetapi juga info tentang 
lalu lintas, ULAS (Unit Layanan Aduan Surakarta) merupakan fitur aduan/ kritik dari masyarakat terhadap pemerintah Kota Surakarta, layanan masyarakat seperti e- retribusi, perijinan IMB serta layanan kependendukan. Fitur lainnya yaitu radio anak, fitur tentang harga pangan/ sembako di pasar tradisional dan informasi umum ATM, RRI Surakarta, jadwal transportasi, Puskesmas, Rumah Sakit, SPBU.

Keunggulan inovasi Solo Destination antara lain mudah digunakan karena aplikasi yang tersedia dalam Solo Destination dapat diunduh di Play Store semua telephone seluler (ponsel) OS Android. Biaya internet semakin murah karena makin banyaknya provider yang menawarkan paket- paket data yang kompetitif dengan jaringan dari mulai Edge, HSDPA, 3G dan $4 \mathrm{G}$ secara tidak langsung berpengaruh pada pengguna aplikasi Solo Destination. Penyedian fitur- fitur yang bervariatif tidak hanya berkaitan dengan pariwisata tetapi juga layanan umum, info lalu lintas dan fitur radio anak yang merupakan radio khusus anak dengan nama Radio Konata (Komunitas Anak Surakarta), semua penyiar radio adalah anak- anak serta lagu yang diperdengarkan semua adalah lagu anak- anak.

Studi mengenai inovasi pelayanan publik telah banyak diteliti. Beberapa penelitian tentang inovasi pelayanan publik antara lain pertama, (Juliarso, 2017:584) melakukan penelitian tentang inovasi pelayanan publik di kantor Kecamatan Cijeungjing, Kabupaten Ciamis. Dari penelitian tersebut mengemukakan bahwa terdapat beberapa inovasi pelayanan publik di kantor Kecamatan Cijeungjing, Kabupaten Ciamis antara lain rehabilitasi ruang pelayanan dan pemanfaatan jejaring sosial untuk lebih memudahkan akses informasi kepada masyarakat. Kedua, ((Rawden, dkk,2017:2) melakukan penelitian di Norwegia tentang faktor manusia dalam implementasi dan adopsi inovasi pelayanan publik bidang kesehatan dengan studi kasus pada pengenalan teknologi baru. Pada fase adopsi pelayanan publik bidang kesehatan di Norwegia mengalami kekacauan dan ketidakstabilan. Mayoritas karyawan yang bekerja di bidang kesehatan mengalami kesulitan dalam mengoperasikan teknologi baru layanan perawatan kesehatan sehingga mengakibatkan ketidakpuasan dalam pemberian pelayanan publik kepada masyarakat. Studi yang dilakukan oleh Batt- Rawden dkk untuk memberikan wawasan dan pengetahuan baru tentang transisi dari penggunaan teknologi lama ke teknologi baru dalam layanan perawatan kesehatan sehingga menciptakan kebutuhan baru tentang inovasi dan implementasi teknologi baru dalam layanan perawatan kesehatan. Dari penelitian tersebut mengemukakan untuk mengatasi faktor manusia dalam implementasi dan adopsi inovasi pelayanan publik bidang kesehatan dengan cara komunikasi yang baik dan interaksi yang berkelanjutan di semua tingkatan organisasi sehingga mencegah kegagalan dalam implementasi dan adopsi inovasi pelayanan publik.

Penelitian ketiga, (Riki dan Fitri, 2019:43) melakukan penelitian tentang inovasi pelayanan publik dalam menghadapi era revolusi industri 4.0 di Kota Bandung mengemukakan bahwa Kota Bandung memiliki berbagai inovasi dalam rangka mengahadapi era revolusi industri 4.0 antara lain inovasi dari Dinas Penanaman Modal dan Pelayanan Terpadu Satu Pintu Kota Bandung meliputi HAYU, Kredit Melati, aplikasi GAMPIL (Gadget Mobile Aplication for 
License) dan Kredit Mesra. Inovasi tersebut diciptakan untuk mempermudah perijinan secara online. Dinas Pendidikan Kota Bandung juga menciptakan inovasi "Si Kasep" merupakan sebuah inovasi seleksi para guru yang potensial menjadi Kepala Sekolah digunakan sebagai kanal pendaftaran administrasi online. Terdapat juga inovasi "Mang Udin" merupakan singkatan dari Mangga Urus Identitas Kependudukan dan Bi Eha akronim dari Bisa Euy Hebat merupakan inovasi Pemerintah Kota Bandung dalam menyelesaikan masalah- masalah kependudukan baik administrasi, akurasi data lahir sampai data kematian

Penelitian keempat dari (Claire dan Fulton,2019:3) mengenai literasi digital dalam perguruan tinggi dengan studi kasus keterlibatan mahasiswa dengan etutorial menggunakan pembelajaran campuran (blended learning). Model pembelajaran tatap muka dan online sangat populer dalam perguruan tinggi khususnya program sarjana dan pascasarjana dengan tujuan meningkatkan minat mahasiswa untuk belajar, mendukung kolaborasi, menumbuhkan kreativitas serta melengkapi mahasiswa dengan berbagai ketrampilan agar dapat bersaing di dunia kerja. Hasil penelitian menunjukkan bahwa e-tutorial memberikan kemudahan akses bagi mahasiswa untuk mendapatkan materi perkuliahan. Terdapat beberapa hambatan bagi mahasiswa ketika menggunakan etutorial antara lain browser sering mengalami gangguan, kualitas suara ketika tutor memberikan materi perkuliahan melalui e- tutorial yang kurang jelas dan masalah koneksi internet sehingga mengganggu proses pembelajaran mahasiswa. Meskipun terdapat hambatan dalam menggunakan e- tutorial, mahasiswa merasa senang karena proses pembelajaran di fasilitasi secara online melalui e- tutorial. Akan tetapi, sebagian besar mahasiswa memilih proses pembelajaran campuran (blanded learning) yaitu kombinasi pembelajaran tatap muka dan online.

Selanjutnya, penelitian kelima dari (Scupola dan Hanne, 2013:27) tentang penggunaan media sosial untuk inovasi layanan merupakan sebuah tantangan. Studi ini dilakukan di perpustakaan sekolah. Hasil studi ini menunjukkan bahwa media sosial terutama blog dibuat untuk mengumpulkan beberapa ide agar menciptakan sebuah inovasi layanan dari pengguna perpustakaan. Blog dibuat secara sederhana tetapi sangat bermanfaat untuk mengumpulkan berbagai ide dari pengguna perpusatakaan. Selain itu, blog juga dimanfaatkan sebagai sarana untuk mendengarkan masukan dan keluhan dari pengguna perpustakaan.

Dari kelima penelitian yang telah dibahas sebelumnya, terdapat persamaan dan perbedaan. Adapun persamaannya yaitu membahas inovasi pelayanan publik. Tetapi, perbedaannya yakni penulis membahas inovasi pelayanan publik bidang pariwisata melalui Solo Destination berupa aplikasi terintegrasi layanan pariwisata dan non pariwisata berbasis mobile sehingga dapat menjadi referensi bagi pemerintah daerah lain untuk berinovasi khususnya di bidang pariwisata karena akan berdampak positif pada peningkatan APBD dan apabila dikelola dengan baik dapat meningkatkan kualitas pelayanan publik terhadap masyarakat. 


\section{METODE PENELITIAN}

Penelitian ini menggunakan metode desk research dengan analisis deskriptif. Desk research merupakan penelitian yang bertujuan untuk mengumpulkan data dan informasi dengan bantuan- bantuan material yang terdapat di ruangan perpustakaan.(Moeleong, 2009:82). Pengumpulan data dilakukan dengan memanfaatkan data sekunder. Data sekunder merupakan data yang tersedia dalam berbagai bentuk. Biasanya data sekunder berwujud data dokumentasi atau data laporan yang telah tersedia. (Azwar, 2001:91). Sumber data sekunder dapat berasal dari berbagai kajian literatur terdiri atas publikasi data sensus dan survei nasional, publikasi pemerintah lainnya serta hasil riset- riset sebelumnya.(Asra, 2014:103). Tahap pengumpulan data sekunder antara lain, pertama, mengumpulkan berbagai bahan pustaka yang akan dipilih menjadi sumber data yang berkaitan tentang tema penelitian ini dan didukung dengan informasi yang relavan. Kedua, melakukan pemilahan data sesuai dengan tema dan fokus penelitian. Ketiga, menjabarkan tentang inovasi pelayanan publik melalui Solo Destination di Kota Surakarta, Jawa Tengah.

\section{HASIL PENELITIAN DAN PEMBAHASAN}

Solo Destination merupakan sebuah inovasi pelayanan publik karena tidak terlepas dari cara baru, pengetahuan baru dan teknologi baru. Sebagaimana dikatakan oleh Yogi dalam Noor (2013:87) bahwa inovasi tidak terlepas dari pengetahuan baru, cara baru, objek baru, teknologi baru dan penemuan baru. Dalam hal ini, Solo Destination merupakan cara baru bagi Pemerintah Kota Surakarta untuk memberikan informasi dan layanan bidang pariwisata dengan mudah dan cepat kepada masyarakat maupun wisatawan baik nusantara serta mancanegara yang ingin berwisata ke Kota Surakarta. Dalam hal memberikan informasi dan layanan kepada masyarakat dan wisatawan, Solo Destination menggunakan teknologi baru yakni dalam bentuk aplikasi yang terintegrasi city guide, media sosial dan pemantauan lalu lintas pertama di Indonesia. Aplikasi Solo Destination dapat diunduh di Play Store semua telephone seluler (ponsel) android. Solo Destination juga merupakan pengetahuan yang baru bagi masyarakat dan wisatawan untuk membantu menjelajah dan menikmati indahnya Kota Surakarta yang merupakan Kota budaya dan kuliner dengan cepat.

Sebuah inovasi tidak hanya mencakup cara baru, pengetahuan baru dan teknologi yang baru tetapi juga karakteristik yang lain atau disebut atribut inovasi. Adapun atribut inovasi Solo Destination sebagai berikut :

1. Relative advantage atau keuntungan relatif

Dalam pelaksanaan inovasi Solo Destination yang telah dilaksanakan sejak tahun 2014 di Kota Surakarta, Jawa Tengah memiliki keuntungan relatif sebagai berikut :

a. Memberikan kemudahan, kepraktisan, kecepatan, keakuratan kepada masyarakat dan wisatawan yang akan berwisata ke Kota Surakarta mengingat Solo Destination berupa aplikasi mobile phone yang dapat di download melalui Play Store pada ponsel android. Aplikasi Solo Destination berisi berbagai fitur seperti kuliner, hotel dan tempat penginapan, tempat wisata, event, pusat perbelanjaan, cuaca, pemantauan lalu lintas yang akan 
Jurnal Administrasi Negara

ISSN : 2598-4039 (Online)

ISSN : 2302-2231 (Print)
Yunita Ratna Sari

Universitas Terbuka berkerja setelah menginstall aplikasi Solo Destination di ponsel android.

b. Memberikan referensi bagi wisatawan nusantara maupun mancanegara untuk memperoleh informasi secara lengkap dan jelas tentang potensi Kota Surakarta dan sekitarnya sehingga saat sudah tiba di Kota Surakarta mereka sudah memperoleh gambaran yang lengkap apa yang diinginkan.

c. Bagi masyarakat yang memerlukan pelayanan masyarakat terdapat fitur perijinan IMB, fitur e- Uji khususnya terkait pendaftaran online layanan pengujian kendaraan bermotor mulai dari syarat, tata cara sampai biaya yang harus dibayar oleh pemohon, fitur layanan kependudukan khususnya Kartu Identitas Anak (KIA) dengan layanan ini tentu mempermudah orang tua yang akan mendaftarkan KIA untuk anaknya karena dengan mengakses Solo Destination maka pemohon dapat melakukan registrasi permohonan KIA secara online kemudian ke Dinas Kependudukan dan Catatan Sipil Kota Surakarta/ Kecamatan untuk mengambil KIA yang sudah jadi.
Dari sisi Dinas Kependudukan dan Catatan Sipil Kota Surakarta jelas terbantu karena mengurangi antrian panjang pemohon, fitur e- retribusi dapat memberi informasi kepada masyarakat mengenai target dan realisasi penerimaan retribusi pasar di Kota Surakarta serta tapping harian masing- masing pedagang yang sudah membayar.

d. Dari sisi ekonomi, Solo Destination akan menarik wisatawan lokal maupun mancanegara untuk tertarik dan membelanjakan uangnya di Kota Surakarta sehingga dapat meningkatkan perekonomian masyarakat di Kota Surakarta yang kaya akan kerajinan batik, craft serta wisata kuliner.

e. Dari sisi Pemerintah bahwa pelaksanaan Solo Destination untuk melayani masyarakat, membantu mensosialisasikan program- program pemerintah, mengedukasi masyarakat untuk memanfaatkan teknologi secara tepat dan benar serta mempermudah masyarakat guna memperoleh layanan langsung dari OPD penyelenggara.

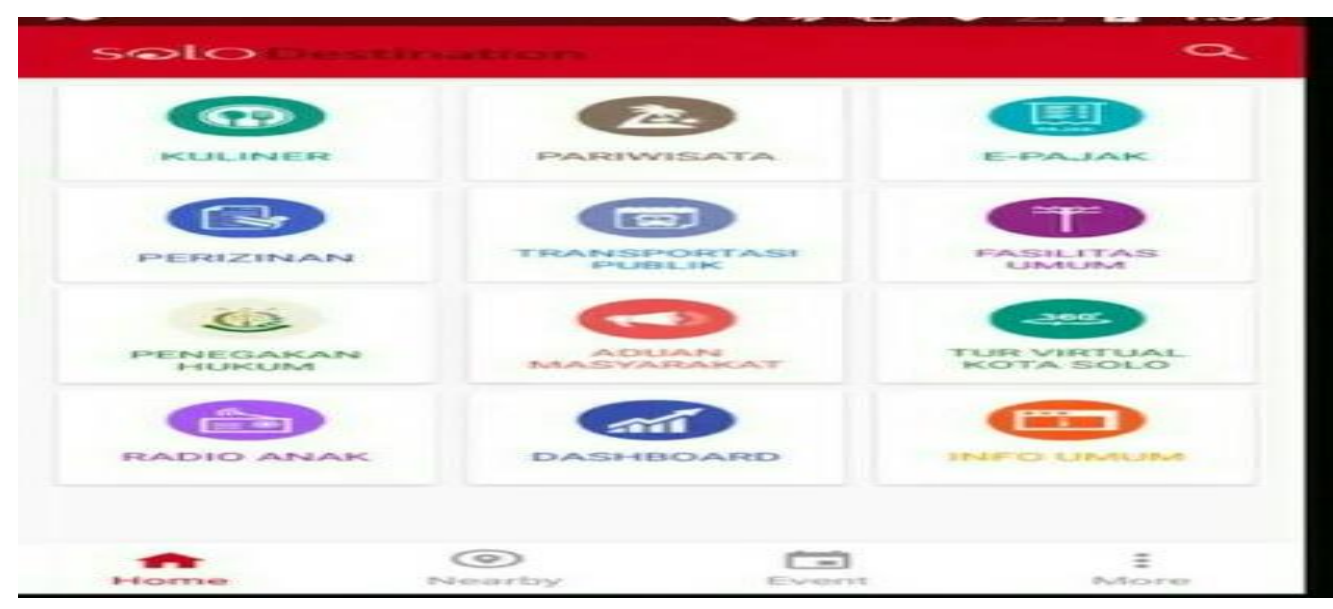

Gambar 1 Fitur dalam Solo Destination

Sumber : Dokumen Bagian Organisasi Sekretariat Daerah Kota Surakarta Tahun 2014 
Jurnal Administrasi Negara

ISSN : 2598-4039 (Online)

ISSN : 2302-2231 (Print)
Yunita Ratna Sari

Universitas Terbuka

\section{Compatibility atau Kesesuaian}

Dalam pelaksanaan inovasi Solo Destination di Kota Surakarta memiliki keterkaitan dan kesesuaian dengan sebelum adanya inovasi Solo Destination. Kesesuaian sebelum dan sesudah adanya inovasi yakni masih melibatkan OPD (Organisasi Perangkat Daerah). Sebelum adanya inovasi Solo Destination di Kota Surakarta, masyarakat dan wisatawan yang ingin memperoleh informasi dan layanan khususnya bidang pariwisata yang ada di Kota Surakarta dengan mendatangi OPD terkait atau membuka website OPD yang terkait. Setelah adanya inovasi Solo Destination, peran OPD masih dilibatkan untuk merealisasikan penggunaan teknologi informasi dalam layanan publik yang diselenggarakan oleh pemerintah daerah. OPD utama yang terlibat dalam inovasi Solo Destination diantaranya Dinas Komunikasi dan Informatika Kota Surakarta sebagai leading sector pelaksaan inovasi sekaligus pengelola aplikasi Solo Destination. Dinas Pariwisata berperan dalam memberi informasi kalender event Kota Surakarta dan tempat- tempat pariwisata, Dinas Perhubungan Kota Surakarta berperan pemberi informasi lalu lintas sekitar Kota Surakarta, Dinas Kesehatan Kota Surakarta berperan sebagai leading sector dari Puskesmas dan Rumah Sakit di Kota Surakarta, Dinas Perdagangan Kota Surakarta memberikan informasi tentang kebutuhan bahan pokok masyarakat, Inspektorat berperan untuk mendampingi dalam konsep penyusunan aplikasi dan pengelola ULAS serta Dinas Kependudukan dan Catatan Sipil Kota Surakarta berperan dalam pendaftaran online Kartu Insentif Anak (KIA).

\section{Complexity atau Kerumitan}

Kerumitan dalam hal ini dapat diartikan sebagai kendala- kendala yang dihadapi dalam pelaksanaan inovasi. Adapun kendala yang dihadapi dalam pelaksanaan inovasi Solo Destination diantaranya perubahan informasi dan layanan yang sangat cepat serta keterlambatan update data dan kurangnya komunikasi antara stakeholder dengan OPD- OPD terkait. Kerumitan lainnya dalam pelaksanaan inovasi Solo Destination yakni pola pikir pengguna yang sulit untuk berubah, lantaran sering ada yang berpikiran mengapa harus menggunakan teknologi informasi kalau yang sudah berjalan dapat terlayani.

4. Triability atau Kemungkinan dicoba

Inovasi Solo Destination sangat mungkin untuk dicoba dan diterapkan di Kota Surakarta mengingat Solo Destination dirancang dalam bentuk aplikasi yang mudah digunakan dengan cara mendownload aplikasi Solo Destination melalui Play Store yang tersedia di ponsel android. Ketika perkembangan teknologi informasi semakin semarak, dimana kebutuhan masyarakat akan layanan dan informasi semakin tinggi, maka tahun 2014, Dinas Komunikasi, Informatika dan Perhubungan Kota Surakarta bekerjasama dengan Telkomsel menggagas sebuah inovasi berupa aplikasi yang mampu mengintegrasikan layanan dan informasi. Setelah berproses 3 bulan, akhirnya diluncurkan sebuah inovasi berbentuk aplikasi bernama "Solo Destination."

Aplikasi Solo Destination dilauncing oleh Bapak Walikota Surakarta FX. Hadi Rudyatmo pada tanggal 8 Juni 2014 pada saat Hari Ulang Tahun Car Free Day Kota Surakarta ke 4 di Jalan Slamet Riyadi, sebuah jalan protokol terbesar di Kota Surakarta. Launching di Car Free Day merupakan pilihan lokasi strategis karena banyaknya jumlah pengunjung di hari Minggu pagi telah memberi efek 
publikasi yang cukup signifikan pada inovasi aplikasi Solo Destination.

Pada saat launching aplikasi Solo Destination mendapat penghargaan dari Museum Rekor Dunia Indonesia atau Muri tahun 2014 sebagai Kota pertama di Indonesia yang menyediakan layanan pariwisata berbasis Teknologi Informasi dan Komunikasi. Hal ini merupakan prestasi yang menggembirakan karena di saat Pemerintah Kabupaten/ Kota yang lain belum menyediakan layanan ini, Kota Surakarta sudah melaunching secara resmi. Dalam kurun waktu 2 tahun 7 bulan sejak dilaunching, Solo Destination telah diunduh sebanyak 10.000 kali. Solo Destination di desain dengan GPS (Global Postioning System) yang membantu keberadaan posisi dan tujuan wisatawan baik lokal maupun mancanegara. Ukuran file aplikasi ini sebesar 5,21 MB dan tidak memberatkan kinerja ponsel. Aplikasi Solo Destination dapat bekerja dengan baik pada android versi Jelly Bean keatas. Aplikasi info lalu lintas pada Solo Destination sebesar 13,1 MB.

Info lalu lintas akan terkoneksi dengan CCTV yang terpasang di sejumlah titik Kota Surakarta dan pemakaian aplikasi lalu lintas akan menyedot paket pulsa $20 \mathrm{Kbps}$. Aplikasi Solo Destination juga menyediakan interaksi bagi pengguna pemberian rating dan komen tempat kuliner dan hotel. Aplikasi ini dapat menjadi rujukan bagi pengelola tempat kuliner dan hotel untuk mengetahui komentar dari para pengguna sehingga ketika mendapat kritik pelayanan bisa segera melakukan perbaikan dan peningkatan pelayanan. Terdapat info terbaru Kota Surakarta meski wisatawan mancanegara kembali ke negara asal sehingga mereka dapat mengetahui semua kegiatan atau event terbaru di Kota Surakarta. Hal ini tentu menjadi media promosi yang cepat dan tepat bagi wisatawan mancanegara.

5. Observasibility atau Kemudahan diamati

Inovasi Solo Destination di Kota Surakarta mudah diamati dari alur penggunaan inovasi tersebut karena Solo Destination merupakan inovasi pelayanan publik berbentuk aplikasi yang terintegrasi dan mudah didownload melalui Play Store di ponsel android. Selain aplikasi Solo Destination mudah didownload juga terdapat berbagai fitur antara lain kuliner (jajanan dan minuman seperti gandos rangin, roti kecik, serabi Solo, leker Solo, gempol pleret, dawet ayu pasar Gede), makan malam (gudeg ceker bu Kasno, nasi liwet, bestik Solo, bakmi toprak Solo), santap siang (pecel ndeso, cabuk rambak, sambel tumpang, selat seger Solo), pariwisata meliputi wisata budaya (Taman Balekembang, Bis Tingkat Werkudoro, Sepur Klutuk Jaladara, Loji Gandrung), wisata religi (GKJ Margoyudan, Klenteng Tridharma, Vihara Dharama Sundara), wisata alam (Agro Sondokoro, Umbul Cokro, Umbul Tlatar), wisata buatan (Solo Car Free Day, Umbul Pengging).

Fitur hotel ada hotel bintang 1, 2, 3, 4, 5, fitur belanja seperti pasar modern (House of Danar Hadi, Pusat Grosir Solo), pasar tradisional (Pasar Burung Depok, Pasar Legi, Pasar Gede, Kampung Batik Laweyan). Fasilitas umum (Puskesmas, Rumah Sakit, SPBU), Event budaya (jadwal kalender event bulan Januari- Desember), layanan masyarakat (ijin perijinan, e- uji, layanan kependudukan), radio anak (siaran radio dengan penyiar anak- anak), harga pangan (daftar harga kebutuhan pokok/ sembako di Pasar Tradisional), info umum (galeri foto, ATM, Nomr Penting, RRI Surakarta, Jadwal Trasnportasi). 


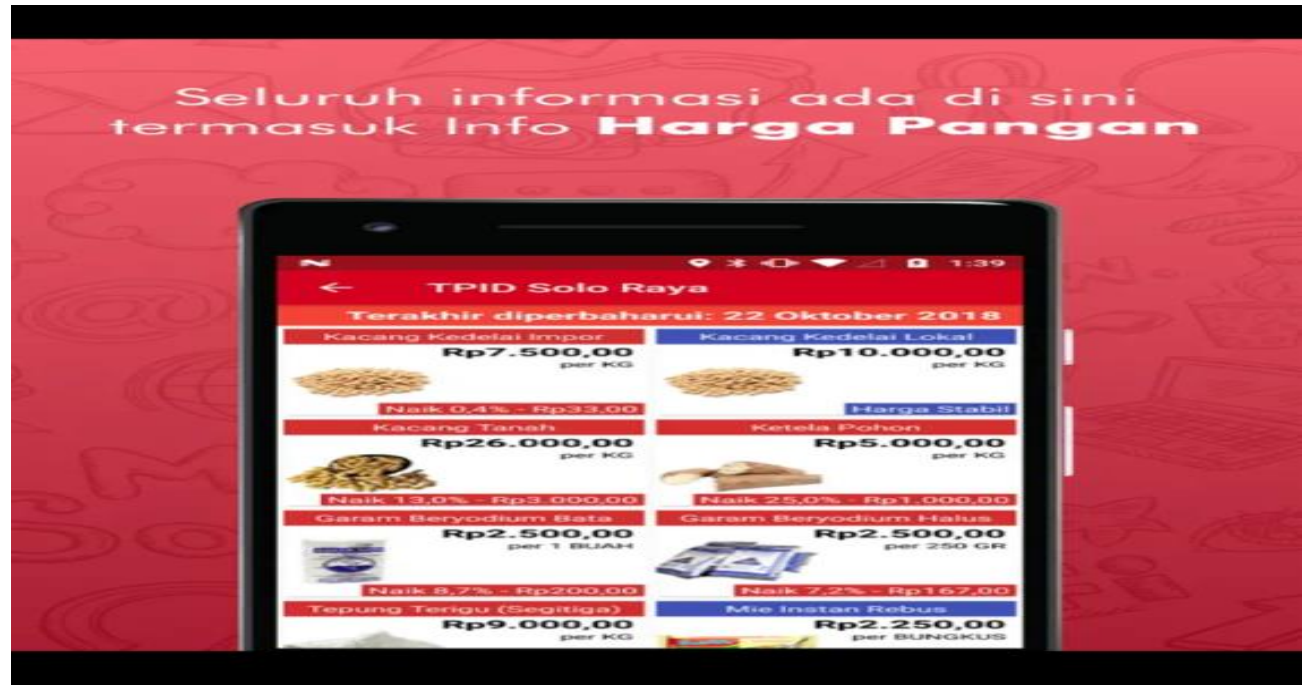

Gambar 2. Informasi Harga Pokok pada Solo Destination Sumber : Dokumen Bagian Organisasi Sekretariat Daerah Kota Surakarta Tahun 2014

Regulasi pelaksanaan inovasi Solo Destination yaitu Peraturan Walikota Surakarta No 27- C Tahun 2016 yang mengatur secara tegas tentang tugas pokok dan fungsi Dinas untuk menyelenggarakan segala hal yang terkait dengan Komunikasi, Informatika, Statistik dan Persandian. Anggaran yang disiapkan untuk inovasi Solo Destination dari APBD Kota Surakarta. Tahun 2014, jumlah anggaran $\mathrm{Rp}$ 50.000.000, tahun 2015 sebesar Rp 200.000.000, tahun 2016 sebesar Rp 200.000.000 serta tahun 2017 sebesar Rp 800.000.000 digabung dengan jasa konsultan perencana aplikasi terintegrasi Solo Destination dan eoffice. Pelaksanaan inovasi Solo Destination melibatkan berbagai stakeholder antara lain pertama, stakeholder internal meliputi OPD di Pemerintah Kota Surakarta terdiri atas Walikota Surakarta, FX. Hadi Rudyatmo sebagai inisiator awal inovasi Solo Destination kemudian ditindaklanjuti koordinasi oleh Wakil Walikota Surakarta, Sekretariat Daerah Kota Surakarta, Dinas Komunikasi dan Informatika Kota Surakarta, Dinas
Perhubungan Kota Surakarta, Dinas Pariwisata Kota Surakarta, Dinas Kesehatan Kota Surakarta, Dinas Kependudukan dan Catatan Sipil Kota Surakarta, Dinas Perdagangan Kota Surakarta serta Badan Pendapatan, Pengelolaan Keuangan Aset Daerah terkait anggaran dan data e retribusi.

Stakeholder eksternal yang terlibat dalam pelaksanaan Solo Destination antara lain Tim TPID (Tim Pemantau Inflasi Daerah sebagai penyedia informasi harga pangan), PT. Gama Techo, PHRI (informasi Hotel), Komunikasi Kuliner Solo, Radio Republik Indonesia Kota Surakarta, Badan Pengembangan Pariwisata Surakarta (BPPS), Rumah Sakit di Kota Surakarta, Angkasa Pura, PMI, Perbankan, Forum Anak Surakarta (FAS). Stakeholder dari instansi vertikal/ BUMN antara lain BPS, Bank Indonesia, PT. KAI serta PLN. Monitoring dalam pelaksanaan Solo Destination dilakukan secara berkala Dinas menyelenggarakan koordinasi dengan berbagai stakeholder terkait untuk membahas perkembangan konten Solo Destination baik dari 
penyelenggara pemerintahan maupun layanan swasta. Adapun temuan penting dalam penelitian ini yaitu inovasi Solo Destination merupakah sebuah inovasi pelayanan publik bidang pariwisata yang dirancang dalam bentuk aplikasi yang terintegrasi city guide, sosial media dan pemantauan lalu lintas berbasis mobile phone pertama di Indonesia. Aplikasi dalam Solo Destination dapat diunduh oleh semua orang terutama wisatawan lokal maupun mancanegara yang akan berkunjung ke Kota Surakarta. Selain itu, aplikasi dalam Solo Destination menyediakan berbagai fitur yang memudahkan para wisatawan memperoleh informasi secara lengkap mengenai potensi Kota Surakarta yang sebelum adanya inovasi Solo Destination para wisatawan yang akan berkunjung ke Kota Surakarta terlebih dahulu mengakses informasi dari masingmasing website OPD, kemudian untuk mengakses informasi dari website masing - masing OPD Kota Surakarta mengenai pariwisata, wisatawan mengahafal namanama websit, informasi mengenai harga pokok pangan biasanya diperoleh dari koran, TV atau getok tular dari masyarakat serta layanan dan informasi dari sektor swasta seperti kuliner, hotel, even budaya dikemas masing- masing pihak penyelenggara.

\section{PENUTUP}

\section{Kesimpulan}

Pelaksanaan inovasi pelayanan publik melalui Solo Destination di Kota Surakarta memberikan manfaat positif bagi semua pihak antara lain bagi pemerintah Kota Surakarta yaitu dapat memberikan pelayanan publik secara cepat kepada masyarakat dan bagi masyarakat serta wisatawan dapat memperoleh berbagai informasi dan layanan di Kota Surakarta dengan mudah.
Dari sisi ekonomi terjadi peningkatan pendapatan dalam APBD Kota Surakarta. Jumlah pendapatan dari jasa lainnya termasuk pariwisata sebesar 305, 614.62 pada tahun 2014 mengalami peningkatan di tahun 2015 sebesar 326,200.52 (Surakarta Dalam Angka 2016). Inovasi aplikasi Solo Destination mengalami kemajuan perkembangan dari sisi waktu, pengguna yang mengunduh Solo Destination sebanyak 10.000 pengguna, fitur semakin berkembang yang awalnya hanya layanan pariwisata dan kuliner berkembang menjadi lebih dari 36 layanan serta stakeholder pendukung layanan Solo Destination sudah didukung lebih 7 OPD dan lebih dari 15 sektor swasta.

\section{Saran}

Rapat koordinasi dan komitmen bersama dengan berbagai stakeholder harus ditingkatkan karena merupakan kunci pokok agar kendala dalam pelaksanaan inovasi aplikasi Solo Destination dapat diatasi serta diselenggarakan forum/ grup media sosial pendukung Solo Destination. Sosialisasi Solo Destination lebih ditingkatkan melalui baliho, leafet, dialog interaktif di Radio, Komunitas Blogger, Twitter di Kota Surakarta untuk bersama- sama mengkampanyekan penggunaan aplikasi Solo Destination agar memudahkan masyarakat dalam mengakses layanan dan informasi publik. 
Jurnal Administrasi Negara

ISSN : 2598-4039 (Online)

ISSN : 2302-2231 (Print)
Yunita Ratna Sari

Universitas Terbuka

\section{REFERENSI}

Ancok,

Djamaludin.

(2012).

Kepemimpinan dan Inovasi. Jakarta :

Penerbit Erlangga.

David Alburry Geoff Mulgan. (2003). Innovation in The Public Sector. Landon : The Mall.

Dinas Kependudukan dan Catatan Sipil Kota Surakarta. (2016). Profil Perkembangan Kependudukan Kota Surakarta Tahun 2016. Retrieved April 18, 2019 from http://dispendukcapil. Surakarta.go.id.

Fery Ardy Susanto. (2018). Capaian Pembangunan Kota Solo Dinilai Terbaik. Retrieved, April 22, 2019 from https://radarsolo.jawapos.com/read/2018/ 05/02/69799/capaian-pembangunan-kotasolo-dinilai-terbaik.

Hardiansyah. 2011. Kualitas Pelayanan Publik, Konsep, Dimensi, Indikator dan Impelementasinya. Yogyakarta : Gava Media.

Hayat. 2017.Manajemen Pelayanan Publik. Jakarta : PT. Rajagrafindo Persada.

Imam Saputro. (2018). Raih WTP 8 Tahun Berturut- Turut, Pemkot Solo Dapat Penghargaan Dari Kemenkeu. Retrieved, April, 21, 2019 from http://solo.tribunnews.com/2018/09/20/ra ih-wtp-8-tahun-berturut-turut-pemkotsolo-dapat-penghargaan-dari-kemenkeu.

Juliarso, Ahmad. (2017). Inovasi Pelayanan Publik di Kantor Kecamatan Cijeungjing, Kabupaten Ciamis. Jurnal Ilmiah Dinamika, (4), (4), 584. Retrieved from https://jurnal.unigal.ac.id.

Mulato Isha'an. (2017). Solo Raih Penghargaan Kota Paling Inovatif 2017. Retrieved, April 20, 2019 from http://m.rri.co.id/post/berita/469742/daera h/solo_raih_penghargaan_kota_paling_in ovatif_2017.html.
McGuiness, Claire dan Crystal Fulton. (2019). Digital Literacy in Higher Education : A Case Study of Student Engagement with E- Tutorials Using Blended Learning. Journal of Information Technology Education : Innovations in Practice, (18), 3. Retrieved http://www.jite.org.

Noor, Irwan. (2013). Desain Inovasi Pemerintahan Daerah. Malang : UB Press.

Ombudsman RI. (2018). Laporan Tahunan 2018. Retrieved April 17, 2019 from https://www.ombudsman.go.id.

Rawden, Kari Bjerke Batt, dkk. (2017). Human Factors in the Implementation and adoption of innovations in health care services. A longitudinal case study on the introduction of new technology. The Innovation Journal : The Public Sector Innovation Journal, (22),(3), 2. Retrieved from https:// www. innovation.cc/volumes-issues/vol 22-no 3.html.

Rogers. Everett M. (2003). Diffusion of Innovations $5^{\text {th }}$ edition. New York : Free Press.

Said, M. Mas'ud. (2007). Birokrasi di Negara Birokratis. Malang : UMM Press.

Scupola, Ada dan Hanne West Nicolajsen. (2013). Using Social Media for Service Innovations : Challenges and Pitfalls. International Journal of EBusiness Research, (9), (3), 27. Retrieved from https://pdfs.semanticscholar.org.

Suwarno. Yogi, (2010). Inovasi Sektor Publik. Jakarta : STIA LAN Press.

Watson, Douglas J. 1997. Innovative Governments: Creative Approaches to Local Problems. New York : Greenwood Publishing Group.

Wasistiono, Sadu.2001. Manajemen Pemerintahan Daerah. Bandung : Alqa Print. 